\title{
OPTIMALISASI KOMUNIKASI ANTAR PRIBADI DALAM PENDIDIKAN MENUJU GENERASI EMAS PADA GURU DAN ORANGTUA PESERTA DIDIK DI SD KESTALAN SURAKARTA
}

\author{
Oktiana Handini ${ }^{1}$ Mukhlis Mustofa ${ }^{2}$ \\ handinioktiana7@gmail.com
}

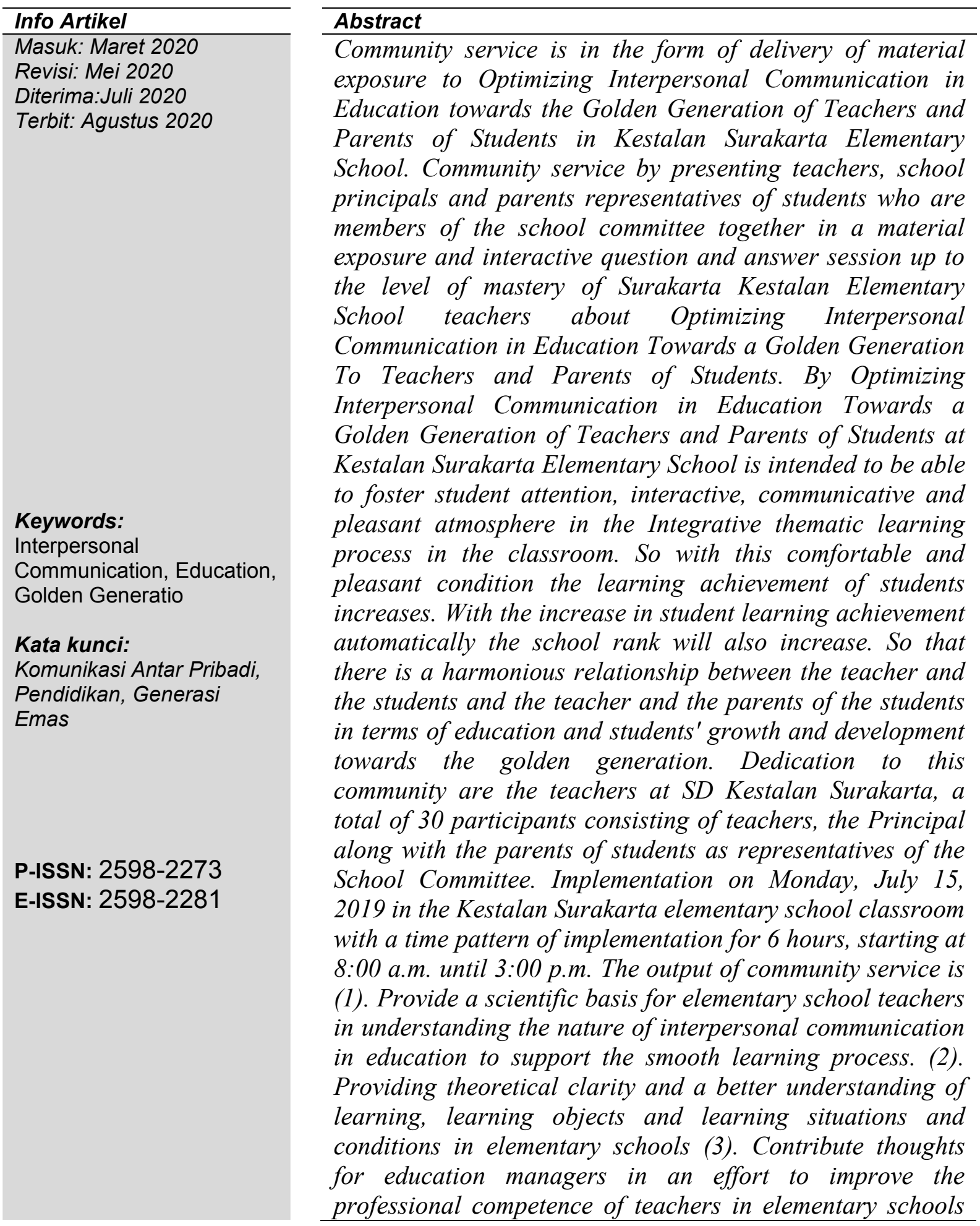


through interpersonal communication in education. (4). Establish communication links between school teachers and parents of students in elementary schools to form integrative communication in education. Furthermore, the results of this community service were presented in the National Seminar on Community Service and published in the ISSN accredited and community service journal.

\footnotetext{
Abstrak

Pengabdian kepada masyarakat ini berupa penyampaian paparan materi Optimalisasi Komunikasi Antar Pribadi Dalam Pendidikan menuju Generasi Emas Pada Guru dan Orangtua Peserta Didik di SD Kestalan Surakarta. Pengabdian kepada masyarakat dengan menghadirkan guru, kepala sekolah dan perwakilan orang tua peserta didik yang tergabung dalam komite sekolah secara bersama-sama dalam acara paparan materi dan tanya jawab interaktif hingga pada level penguasaan guru SD Kestalan Surakarta tentang Optimalisasi Komunikasi Antar Pribadi Dalam Pendidikan Menuju Generasi Emas Pada Guru dan Orangtua Peserta Didik. Dengan Optimalisasi Komunikasi Antar Pribadi Dalam Pendidikan Menuju Generasi Emas Pada Guru dan Orangtua Peserta Didik di SD Kestalan Surakarta ini dimaksudkan agar mampu menumbuhkan atensi peserta didik, interaktif, komunikatif dan suasana yang menyenangkan dalam proses pembelajaran tematik Integratif di kelas. Sehingga dengan kondisi yang nyaman dan menyenangkan ini prestasi belajar peserta didik meningkat. Dengan meningkatnya prestasi belajar peserta didik secara otomatis akan meningkat pula peringkat sekolah tersebut. Sehingga terjalin hubungan harmonis antara guru dengan peserta didik dan guru dengan orang tua peserta didik dalam hal pendidikan dan tumbuh kembang peserta didik menuju generasi emas. Pengabdian kepada masyarakat ini adalah guru-guru di SD Kestalan Surakarta, sejumlah 30 peserta yang terdiri dari guru ,Kepala Sekolah beserta orang tua peserta didik sebagai perwakilan Komite Sekolah. Pelaksanaan pada hari Senin 15 Juli 2019 di ruang kelas SD Kestalan Surakarta dengan pola waktu pelaksanaan selama 6 jam, mulai pukul 8.00 wib hingga pukul 15.00 wib. Luaran pengabdian kepada masyarakat ini adalah (1). Memberikan dasar ilmiah bagi guru Sekolah Dasar dalam memahami hakikat komunikasi Antar Pribadi dalam pendidikan guna mendukung kelancaran proses pembelajaran. (2). Memberikan kejelasan secara teoritis dan pemahaman yang lebih baik tentang belajar, obyek belajar serta situasi dan kondisi belajar di Sekolah Dasar.(3). Memberikan kontribusi pemikiran bagi pengelola pendidikan dalam upaya meningkatkan kompetensi profesional guru di Sekolah Dasar melalui komunikasi antar pribadi dalam pendidikan. (4). Menjalin hubungan komunikasi antara guru dari pihak sekol;ah dan orangtua peserta didik di Sekolah Dasar agar terbentuk komunikasi integratif dalam pendidikan. Selanjutnya hasil pengabdian kepada masyarakat ini dipresentasikan dalam Seminar Nasional Pengabdian Kepada Masyrakat dan dipublikasikan dalam jurnal pengabdian masyarakat terakreditasi dan ber ISSN.
} 


\section{PENDAHULUAN}

Perubahan kurikulum dan pengembangan pembelajaran yang dilakukan oleh pemerintah saat ini bertujuan untuk pengembangan kurikulum pendidikan di Indonesia seiring dengan kemajuan zaman. Langkah penting bagi dunia pendidikan merupakan kesempatan emas untuk berpartisipasi memanfaatkan bonus demografi menjadi sebuah tantangan, Saat ini pendidikan bertumpu pada upaya mencapai Pendidikan Dasar untuk Semua. Semua warga negara yang akan berada pada tahun 2045 harus disiapkan sejak saat ini dengan bekal pendidikan dasar yang bermutu. Pendidikan dasar yang bermutu, yaitu pendidikan dasar yang mampu membekali generasi emas kita menjadi keberuntungan. Melalui pendidikan dasar yang bermutu diyakini, Generasi Emas Tahun 2045 mampu mewujudkan puncak peradabannya Kompetensi dan keterampilan para guru yang terkini adalah (1) Technologi literacy, (2) Knowledge deepening, dan (3) Knowledge creation (Zuhdan K Prasetyo 2019). Yang memayungi enam komponen sistem pendidikan, yaitu kebijakan, kurikulum \& penilaian, pedagogi, teknologi informasi dan komunikasi, organisasi \& administrasi, dan pengembangan profesi guru. kebutuhan komunikasi dan berinteraksi dengan lingkungannya, sehingga diperlukan kemampuan berbahasa. Kemampuan Berkomunikasi dan Kemampuan Menyatakan Dirinya, Kemampuan Menyesuaikan Dirinya serta Kemampuan Membawakan Dirinya melalui jalur pengembangan diri.

Saat ini di Sekolah Dasar pembelajaran dengan pendekatan saintifik, dimana pembelajaran yang terdiri atas kegiatan mengamati (untuk mengidentifikasi hal-hal yang ingin diketahui), merumuskan pertanyaan (dan merumuskan hipotesis), mencoba/mengumpulkan data (informasi) dengan berbagai teknik, mengasosiasi/ menganalisis/mengolah data (informasi) dan menarik kesimpulan serta mengkomunikasikan hasil yang terdiri dari kesimpulan untuk memperoleh pengetahuan, keterampilan dan sikap.

Dalam upaya memperluas wawasan pembelajaran, pola komunikasi antar pribadi baik antara guru dengan peserta didik maupun guru dengan orangtua peserta didik. Hal ini memberikan peluang bagi guru untuk berpikir kritis dan kreatif. Sehingga membantu guru dan orangtua peserta didik berkomunikasi aktif, berkolaborasi, saling mengemukakan gagasan, menemukan masalah, menentukan alternatif pemecahan masalah dan saling berinteraksi. Dengan demikian akan membangun komunikasi interpersonal maupun komunikasi intrapersonal yang mendukung prestasi akademik peserta didiknya.

\section{ANALISA SITUASI}

Para guru di sekolah dasar saat ini dalam melaksanakan pembelajaran masih klasik dan tradisional, pembelajaran dilakukan masih rutinitas sehari-hari dengan bahasa komunikasi pendidikan yang monoton dan terpusat pada guru. Fenomena lainnya yang ada saat menunjukkan bahwa kegiatan belajar peserta didik pada 
umumnya masih sebatas menjalankan instruksi guru, peserta didik kurang aktif, peserta didik tidak memiliki keberanian mengungkap pendapat diri secara spontan bila tidak diberi kesempatan dan pertanyaan guru. Sehingga suasana belajar di kelas menjadi tidak kondusif dan cenderung kaku. Keadaan seperti ini menjadi permasalahan guru dalam proses pembelajarannya, sehingga peran guru menjadi sangat dominan dalam permasalahan ini. Padatnya aktivitas guru dalam mengerjakan admnistrasi sekolah menyita waktu guru berinteraksi dan berkomunikasi dengan peserta didiknya. Hasil penelitian menunjukkan bahwa tanggungjawab guru dalam menghadapi kurikulum 2013 yang menuntut komunikasi dengan peserta didik masih rendah (Oktiana Handini 2018). Komunikasi dengan orangtua peserta didik kurang maksimal dan terbatas pada agenda pertemuan rutin dengan paguyuban orangtua peserta didik dan komite sekolah. Pola komunikasi antar pribadi yang dilakukan belum maksimal dan periodik dengan media interaksi yang mendukung.

\section{PERMASALAHAN MITRA}

Sesuai hasil observasi dan wawancara dengan beberapa guru dan kepala sekolah SD Kestalan Surakarta, kegiatan belajar peserta didik pada umumnya masih sebatas menjalankan instruksi guru, peserta didik kurang aktif, peserta didik tidak memiliki keberanian mengungkap pendapat diri secara spontan bila tidak diberi kesempatan dan pertanyaan guru. Sehingga suasana belajar di kelas menjadi tidak kondusif, cenderung kaku dan sedikit membosankan. Kondisi seperti ini biasanya terlihat pada jam pelajaran siang dan pembelajaran yang tidak disenangi peserta didik. Keadaan seperti ini menjadi permasalahan guru dalam proses pembelajarannya, sehingga peran guru menjadi sangat dominan dalam permasalahan ini. Sedangkan guru tidak banyak komunikatif maupun membawa suasana pembelajaran yang menyenangkan. Para guru di sekolah dasar saat ini dalam melaksanakan pembelajaran masih klasik dan tradisional, maksudnya seperti yang biasa dilakukan masih rutinitas sehari-hari. saat menunjukkan bahwa kegiatan belajar peserta didik pada umumnya masih sebatas menjalankan instruksi guru., peserta didik kurang aktif, peserta didik tidak memiliki keberanian mengungkap pendapat diri secara spontan bila tidak diberi kesempatan dan pertanyaan guru. Sehingga suasana belajar di kelas menjadi tidak kondusif dan cenderung kaku. Keadaan seperti ini menjadi permasalahan guru dalam proses pembelajarannya, sehingga peran guru menjadi sangat dominan dalam permasalahan ini.

Fenomena kedua, orang tua peserta didik tidak sepenuhnya memberkan perhatian yang maksimal kepada anaknya melalui layanan komunikasi mendidik di rumah. Misalnya mendamping belajar, menonton televisi maupun bermain. Hal ini disebabkan kesibukan pekerjaan mereka dan latar belakang kemampuan ketrampilan komunikasi mendidik yang tidak terarah. Sedangkan fenomena ketiga, Komunikasi dengan orangtua peserta didik kurang maksimal dan terbatas pada agenda pertemuan rutin dengan paguyuban orangtua peserta didik dan komite sekolah. 


\section{SOLUSI}

Penyampaian materi tentang Optimalisasi Komunikasi Antar Pribadi Dalam Pendidikan Menuju Generasi Emas Pada Guru dan Orangtua Peserta Didik dengan kajian praktis tentang komunikasi Antar Pribadi yang dikaitkan dengan kemajuan di era generasi emas abad 21. Mengacu teori empat aturan penting dalam pembelajaran abad ke-21 yaitu (1) Instruksi harus berpusat pada siswa (2) Pendidikan harus kolaboratif (3) Pembelajaran harus memiliki konteks, dan (4) Sekolah harus diintegrasikan dengan masyarakat ( Jenifer Rita Nicoln, 2017) dan Parents, teachers, school administrators, and policymakers require a clear vision of what our children now need to learn to be successful. (Bernie Trilling and Charles Fadel.,2009).

Komunikasi sangat penting bagi semua aspek kehidupan manusia. Sangat penting bagi setiap individu untuk memahami simbol-simbol yang digunakan dalam komunikasi, baik simbol verbal maupun nonverbal. Komunikasi antar pribadi (interpersonal) adalah komunikasi yang melibatkan dua orang atau lebih. Komunikasi antar pribadi (interpersonal communication) adalah komunikasi antara individuindividu (Littlejohn, 1999). Komunikasi antar pribadi atau Komunikasi interpersonal adalah penggunaan bahasa atau pikiran yang terjadi di dalam diri komunikator sendiri. Komunikasi antar pribadi merupakan keterlibatan internal secara aktif dari individu dalam pemrosesan simbolik dari pesan-pesan. Seorang individu menjadi pengirim sekaligus penerima pesan, memberikan umpan balik bagi dirinya sendiri dalam proses internal yang berkelanjutan. Komunikasi antar pribadi dapat menjadi pemicu bentuk komunikasi yang lainnya. Pengetahuan mengenai diri pribadi melalui proses-proses psikologis seperti persepsi dan kesadaran (awareness) terjadi saat berlangsungnya komunikasi intrapribadi oleh komunikator. Untuk memahami apa yang terjadi ketika orang saling berkomunikasi, maka seseorang perlu untuk mengenal diri mereka sendiri dan orang lain. Karena pemahaman ini diperoleh melalui proses persepsi. Maka pada dasarnya letak persepsi adalah pada orang yang mempersepsikan, bukan pada suatu ungkapan ataupun obyek.

Bentuk khusus dari komunikasi antarpribadi ini adalah komunikasi diadik yang melibatkan hanya dua orang secara tatap-muka, yang memungkinkan setiap pihak menangkap reaksi orang lain secara langsung, baik secara verbal ataupun nonverbal, seperti suami-isteri, dua sejawat, dua sahabat dekat, seorang dosen dengan seorang mahagurunnya, dan sebagainya.

Steward L. Tubbs dan Sylvia Moss (dalam Deddy Mulyana, 2005) mengatakan ciri-ciri komunikasi diadik adalah (1) Peserta komunikasi berada dalam jarak yang dekat, (2) Peserta komunikasi mengirim dan menerima pesan secara simultan dan spontan, baik secara verbal maupun nonverbal.

Komunikasi antarpribadi sangat potensial untuk menjalankan fungsi instrumental sebagai alat untuk mempengaruhi atau membujuk orang lain, karena kita dapat menggunakan kelima lat indera kita untuk mempertinggi daya bujuk pesan yang kita komunikasikan kepada komunikan kita. Sebagai komunikasi yang paling 
lengkap dan paling sempurna, komunikasi antarpribadi berperan penting hingga kapanpun, selama manusia masih mempunyai emosi. Kenyataannya komunikasi tatap-muka ini membuat manusia merasa lebih akrab dengan sesamanya, berbeda dengan komunikasi lewat media massa seperti surat kabar, televisi, ataupun lewat teknologi tercanggihpun.

Jalaludin Rakhmat (1994) meyakini bahwa komunikasi antarpribadi dipengaruhi oleh persepsi interpersonal; konsep diri; atraksi interpersonal; dan hubungan interpersonal. 1. Persepsi interpersonal, 2. Atraksi interpersonal. Hal tersebut dapat penulis deskripsikan sebagai berikut:

1. Persepsi interpersonal : Persepi interpersonal adalah memberikan makna terhadap stimuli inderawi yang berasal dari seseorang(komunikan), yang berupa pesan verbal dan nonverbal. Kecermatan dalam persepsi interpersonal akan berpengaruh terhadap keberhasilan komunikasi, seorang peserta komunikasi yang salah memberi makna terhadap pesan akan mengakibat kegagalan komunikasi.

2. Atraksi interpersonal : Atraksi interpersonal adalah kesukaan pada orang lain, sikap positif dan daya tarik seseorang. Komunkasi antarpribadi dipengaruhi atraksi interpersonal dalam hal: a. Penafsiran pesan dan penilaian. Pendapat dan penilaian kita terhadap orang lain tidak semata-mata berdasarkan pertimbangan rasional, kita juga makhluk emosional. Karena itu, ketika kita menyenangi seseorang, kita juga cenderung melihat segala hal yang berkaitan dengan dia secara positif. Sebaliknya, jika membencinya, kita cenderung melihat karakteristiknya secara negatif. b. Efektivitas komunikasi. Komunikasi antarpribadi dinyatakan efektif bila pertemuan komunikasi merupakan hal yang menyenangkan bagi komunikan. Bila kita berkumpul dalam satu kelompok yang memiliki kesamaan dengan kita, kita akan gembira dan terbuka. Bila berkumpul dengan denganorang-orang yang kita benci akan membuat kita tegang, resah, dan tidak enak. Kita akan menutup diri dan menghindari komunikasi.

Hubungan interpersonal dapat diartikan sebagai hubungan antara seseorang dengan orang lain. Hubungan interpersonal yang baik akan menumbuhkan derajad keterbukaan orang untukmengungkapkan dirinya, makin cermat persepsinya tentang orang lain dan persepsi dirinya, sehingga makin efektif komunikasi yang berlangsung di antara peserta komunikasi. Miller (1976) dalam Explorations in Interpersonal Communication, menyatakan bahwa "Memahami proses komunikasi interpersonal menuntut hubungan simbiosis antara komunikasi dan perkembangan relasional, dan pada gilirannya (secara serentak), perkembangan relasional mempengaruhi sifat komunikasi antara pihak-pihak yang terlibat dalam hubungan tersebut.".

\section{TARGET LUARAN}

Hasil yang dari pelaksanaan pengabdian ini dapat memberikan pemahaman tentang Memberikan dasar ilmiah bagi guru Sekolah Dasar dalam memahami hakikat komunikasi Antar Pribadi dalam pendidikan guna mendukung kelancaran proses 
pembelajaran serta kejelasan secara teoritis dan pemahaman yang lebih baik tentang belajar, obyek belajar serta situasi dan kondisi belajar di Sekolah Dasar. Dengan harapan berkontribusi pemikiran bagi pengelola pendidikan dalam upaya meningkatkan kompetensi profesional guru di Sekolah Dasar melalui komunikasi antar pribadi dalam pendidikan. Sehingga terjalin hubungan komunikasi antara guru dari pihak sekol;ah dan orangtua peserta didik di Sekolah Dasar agar terbentuk komunikasi integratif dalam pendidikan. Langkah pengabdian masyarakat di SD Kestalan ini : a. Melaksanakan Paparan Materi, b. Bertanggung jawab terhadap keberhasilan program, c. Melaksanakan MOU d. Mengontrol tahapan keberhasilan pekerjaan e. Pengambil keputusan saat terjadi masalah e.Melaksanakan MONEV $\mathrm{f}$. Menyerahkan hasil kegiatan ke mitra g. Melaporkan pencapaian target kepada Lembaga h. Melakukan Pendampingan pada mitra.

Dengan terlaksananya pengabdian masyarakat ini hasil pengabdian diseminarkan dalam Seminar Nasional Pengabdian Masyarakat Tahun 2019 yang diselenggarakan Universitas Slamet Riyadi pada bulan September 2019 dan dipublikasikan pada jurnal pengabdian masyarakat.

\section{PENUTUP}

Berdasarkan uraian sebelumnya maka dapat disampaikan bahwa kegiatan pengabdian masyarakat tentang Optimalisasi Komunikasi Antar Pribadi Dalam Pendidikan menuju Generasi Emas Pada Guru dan Orangtua Peserta Didik di SD Kestalan Surakarta menghasilkan kesimpulan sebagai berikut:

a. Pengabdian masyarakat tentang Optimalisasi Komunikasi Antar Pribadi Dalam Pendidikan menuju Generasi Emas Pada Guru dan Orangtua Peserta Didik di SD Kestalan Surakarta yang dilaksanakan dapat meningkatkan komunikasi efektif antara guru, peserta didik dan orangtua peserta didik guna menukung capaian keberhasilan belajar peserta didik di Sekolah Dasar.

b. Pengabdian masyarakat tentang Optimalisasi Komunikasi Antar Pribadi Dalam Pendidikan menuju Generasi Emas Pada Guru dan Orangtua Peserta Didik di SD Kestalan Surakarta mampu mengoptimalkan komunikasi efektif antara guru, peserta didik dan orangtua peserta didik guna menukung capaian keberhasilan belajar peserta didik di Sekolah Dasar. di Sekolah Dasar.

\section{SARAN}

Berdasarkan kesimpulan di atas dapat dikemukakan beberapa saran sebagai berikut: 
a. SD Kestalan Surakarta mengoptimalkan komunikasi efektif antara guru, peserta didik dan orangtua peserta didik yang berorientasi pada belajar peserta didik aktif dan efektif guna mendukung capaian keberhasilan belajar peserta didik di Sekolah Dasar.

b. Guru-guru SD Kestalan Surakarta hendaknya memiliki kontribusi pemikiran bagi guru-guru sekolah dasar lainnya dalam upaya mengoptimalkan komunikasi efektif antara guru, peserta didik dan orangtua peserta didik yang berorientasi pada belajar peserta didik aktif dan efektif guna mendukung capaian keberhasilan belajar peserta didik di Sekolah Dasar dengan berbasis penciptaan suasana pembelajaran yang interaktif, nyaman dan kondusif.

c. SD Kestalan Surakarta perlu memfasilitasi sarana media medsos, buku penghubung dan kartu kendali informasi dan komunikasi antara guru dan orang tua peserta didik guna pendukung penbelajaran.

\section{DAFTAR PUSTAKA}

Damanik, Irvando. " Kepala Daerah Kena OTT Masih Bergaya, Masihkah Ada Budaya Malu?". Kompasiana. $6^{\text {th }}$ Juni 2018.

Huda, Nurul. " Kurikulum Pendidikan Hukum Pasca Revolusi 4.0, Keniscayaan sebagai Pilihan!". Speech. Seminar Nasional Unikal 2018 Job Outlook Mencari atribut Ideal Lulusan Perguruan Tinggi. Faculty of Law Universitas Pekalongan. Pekalongan. November $11^{\text {th }}, 2018$.

Putra, Nanda Perdana. March 22" . 2010. "BNN Ungkap Selundupan $10 \mathrm{Kg}$ Sabu Jaringan Malaysia di Batam". Available on website: http://news.liputan6.com/read/3031865 bnn-ungkap-selundupan-10-kg-sabujaringan-malaysia-di-batam. Accessed on December $13^{\text {th }}, 2010$.

Saefudin, Yusuf, et. al. "Urgency of Integrated Assessment on Drugs Crime (A Study in Purbalingga Regency)". Jurnal Dinamika Hukum. Vol. 17 No. 1. January 2017. Pp. 40-52. DOI: 10.20884/1.jdh.2017.17.1.818

Raharjo, Agus. 2017. Cyber Space. Yogyakarta: Genta Publishing. 